\title{
PENDIDIKAN KARAKTER DALAM BUKU PUISI HYANG KARYA ABDUL WACHID B.S. (ANALISIS PROFETISME KUNTOWIJOYO)
}

\author{
Faiz Adittian \\ Institut Agama Islam Negeri Purwokerto \\ Jalan Jendral Ahmad Yani No.40-A, Purwanegara, Purwokerto Utara, \\ Purwanegara, Purwokerto Tim., Kabupaten Banyumas, Jawa Tengah 53126 \\ Email: faiz.adit11@yahoo.com \\ DOI: $10.29313 /$ tjpi.v7i1.3630 \\ Accepted: March 26th, 2018. Approved: July 16th, 2018. Published: July 16th, 2018
}

\begin{abstract}
Prophetic literature is a literary work based on prophetic characteristics. The pillars of prophetic literature are divided into the transcendence dimensions, the liberation dimensions, and the bumanism dimensions. As in this research, in Hyang poetry book by Abdul Wachid B.S. contain with a strong prophetic value in divine and social values. Of course, each poem that written is the actualization of life that reflect the poet's personalities. From this prophetic poetry, will be searched the value of character education that contained in the literary works (poetry). So with poetry, the reader will find the value of character education in poetry that presented by the poet in his poetry.
\end{abstract}

Keywords: Prophetic Literature, Hyang Poetry Book, The Value Of Character Education

ABSTRAK

Sastra profetik. merupakan karya sastra yang berlandaskan atas sifat-sifat kenabian. Pilar sastra profetik, terbagi ke dalam dimensi transendensi, dimensi liberasi, dan dimensi bumanisme. Seperti dalam penelitian ini, di dalam buku puisi Hyang karya Abdul Wachid B.S. banyak mengandung nilai profetik. yang kental akan nilai-nilai ketuhanan dan sosial. Tentunya, setiap puisi yang dituliskan merupakan aktualisasi dari kebidupan yang mencerminkan kepribadian penyair itu sendiri. Berangkat dari puisi profetik ini, akan dicari nilai pendidikan karakter yang terkandung di dalam karya sastra (puisi). Sebingga melalui puisi, pembaca akan menemukan nilai pendidikan karakter di dalam puisi yang disugubkan oleh penyair di dalam puisinya.

Kata Kunci: Sastra Profetik, Buku Puisi Hyang, Nilai Pendidikan Karakter. 


\section{PENDAHULUAN}

Seni merupakan kebutuhan manusia yang asasi untuk memenuhi kepuasannya terhadap keindahan; dalam pengertian ini tercakup keterpesonaan, imajinasi, pengungkapan dan penghayatan emotif, serta makna-makna yang berkaitan dengan fungsinya bagi pemenuhan kebutuhan hidup manusia secara universal. Sebagai salah satu unsur kebudayaan, kesenian tidak hanya menyentuh dimensi keindahan semata-mata, tetapi senantiasa tidak pernah terlepas dari masalah keseluruhan kebudayaan. Cara berpikir, suasana cita rasa, diafragma pandangan kesejagatan, dan kebijakan mengelola kehidupan, kesemuanya berkaitan dengan gugusan nilai, makna, moral, keyakinan, serta pengetahuan yang menyeluruh dalam kebudayaan di mana kesenian itu hidup (Mawardi: 133).

Melalui produk senilah yang akan membawa pemikiran seseorang bisa melihat bagaimana perilaku yang dimiliki oleh para sastrawan. Sastra yang baik adalah sastra yang mampu mencapai nilai estetika tertinggi dan menjadi bagian yang tidak terpisahkan di dalam kehidupan penciptanya. Seperti halnya yang dilakukan oleh banyak penyair-penyair besar Indonesia. Misalnya saja Gus Mus (A. Mustofa Bisri), Sutardji Calzoum Bachri, Abdul Hadi W.M., Emha Ainun Najib, Taufik Ismail, Goenawan Mohammad dan lain sebagainya. Spirit puisi yang dibawa oleh penyair tersebut tidak hanya bentuk estetika saja, akan tetapi banyak mengandung nilainilai lain sebagai bentuk komunikasi internal antara penulis dan pembaca.

Melalui sebuah puisi, maka kita bisa menelusuri kepribadian penyairnya. Sebab sesuatu yang dituliskan merupakan transendensi dari kehidupan yang dialami oleh seorang penulis. Termasuk di dalamnya adalah puisi-puisi Abdul Wachid B.S. yang banyak menyajikan nilai-nilai akhlak melalui puisi profetiknya. Apabila kita kaji lebih dalam, maka akan didapati banyak sekali nilai-nilai moral, sosial, spiritual dan lain sebagainya. Misalnya dalam buku kumpulan puisi Hyang, penyair banyak menyuguhkan simbol-simbol profetik yang dilihat dalam konteks ini mencerminkan akhlak penyair. Oleh sebab itu, menarik untuk mengkaji puisi-puisi yang terantologikan dalam buku Hyang untuk menggali pendidikan karakter yang bercermin dari puisi profetik di dalam buku tersebut.

\section{PEMBAHASAN}

\section{Pendidikan Karakter dalam Islam}

Secara bahasa, kata karakter diartikan dengan tabiat, watak, sifat-sifat kejiwaan, akhlak atau budi pekerti yang membedakan seseorang dengan yang lain (Pusat Bahasa Departemen Pendidikan Nasional, 2008: 521). Sedangkan menurut istilah, karakter adalah cara berfikir dan berperilaku yang menjadi ciri khas seseorang untuk hidup dan bekerjasama, baik dalam lingkungan keluarga, masyarakat, bangsa dan negara. Individu yang berkarakter baik adalah individu yang bisa membuat keputusan dan siap mempertanggungjawabkan setiap akibat dari keputusan yang ia buat( Hamid dan Saebani, 2013: 37).

Dengan makna seperti itu berarti karakter identik dengan kepribadian atau akhlak. Doni Koesoema (2007: 80) mengatakan bahwa Kepribadian merupakan ciri, karakteristik, atau sifat khas diri seseorang yang bersumber dari bentukanbentukan yang diterima dari lingkungan, misalnya keluarga pada masa kecil dan sifat pembawaan sejak lahir.

Di dalam agama Islam, setiap muslim ditekankan untuk menyempurnakan akhlak. Melalui berbagai disiplin ilmu, dalam Islam sering kali menekankan kepada penggunaan akal dan al-Quran guna mengetahu lebih dalam tentang suatu bagaimana mengembangkan kepribadian. Misalnya saja dalam menyoroti pendidikan karakter merupakan langkah penting dan strategis dalam membangun jati diri seseorang. Oleh sebab itu perlu dicermati secara lebih menyeluruh mengenai akhlak ini. 
Imam al-Ghazali mendefinisikan bahwa akhlak akhlak adalah keadaan sifat yang tertanam dalam jiwa yang dirinya muncul perbuatan-perbuatan mudah, tanpa memerlukan pemikiran dan pertimbangan. Seperti halnya akhlak, secara substansi etika juga memiliki makna yang sama dengan moral. Tetapi, secara terminologis dalam posisi tertentu, etika memiliki makna yang berbeda dengan moral. Sebab etika memiliki tiga posisi, yakni sebagai sistem nilai, kode etik, dan filsafat moral.

Sebagai sistem nilai, etika berarti nilai-nilai dan norma-norma moral yang menjadi pegangan bagi seseorang atau kelompok dalam mengatur tingkah lakunya. Dalam posisi inilah sebagian besar makna etika dipahami sehingga muncul istilah "Etika Islam". Dalam posisi ini pula makna etika sama dengan moral. Pengertian moral sebagai sistem nilai dapat juga dilihat dalam definisi Franz Magnis Suseno yang mengartikan etika sebagai keseluruhan norma dan penilaian yang digunakan oleh masyarakat untuk mengetahui bagaimana seseorang seharusnya menjalankan kehidupannya, bagaimana seseorang membawa diri, serta sikap-sikap dan tindakan mana yang harus seseorang kembangkan agar hidupnya sebagai manusia itu berhasil (Arifin, 2002: 14-16).

Bila dilihat dari pengertian karakter dan akhlak di atas, secara substansi bahwa karakter merupakan aplikasi/penerapan akhlak. Penyebutan akhlak itu sendiri merupakan sebuah hasil dari ibadah dan muamalah (syariat Islam) dalam proses kehidupan sehari-hari. Tentunya proses ini berdasarkan atas hukum Islam (al-Quran dan Sunah) yang tidak lain dan tidak bukan untuk menciptakan muslim yang berakhlak mulia. Dengan memiliki sifat tersebut, maka seorang muslim tentunya akan memiliki ketakqwaan kepada Allah dan akan menjauhi segala larangannya. Misalnya saja, seseorang yang memiliki akhlak yang baik, maka tindakan/budi pekertinya akan baik pula. Dalam artian bahwa akhlak lebih kompleks karena berkaitan dengan syariat yang digunakan untuk mendapatkan akidah yang benar. seperti yang terkandung dalam Q.S. al-Ankabut Ayat 45:

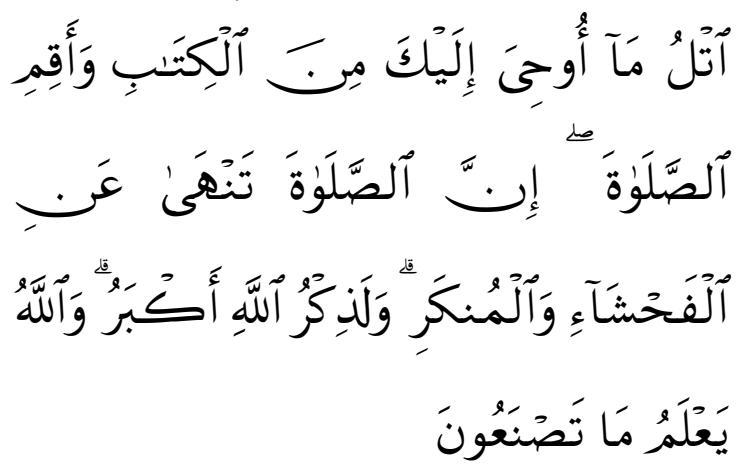

Artinya: "Bacalab apa yang Telah diwabyukan kepadamu, yaitu Al Kitab (Al Quran) dan Dirikanlah shalat. Sesunggubnya shalat itu mencegah dari (perbuatan- perbuatan) keji dan mungkar. dan Sesunggubnya mengingat Allah (shalat) adalah lebih besar (keutamaannya dari ibadat-ibadat yang lain). dan Allah mengetahui apa yang kamu kerjakan."

Bila seseorang muslim melaksanakan shalat atau ibadah yang telah ditentukan sesuai syariat, maka akan membawa sebuah kedamaian atau pemenuhan kebutuhan spiritual yang menciptakan perasaan tenang, selalu berbuat kebaikan, dan terhindar dari perbuatan keji (munkar). Melihat ayat tersebut, dapat kita simpulkan bahwa dasar Islam adalah panduan untuk melaksanakan syariat. Melalui ibadah, maka akan tercipta akhlak mulia yang ditunjukkan melalui perbuatan (karakter) baik terhadap masyarakat. Melalui sarana inilah yang dapat mengantarkan seseorang muslim untuk bersikap dan berperilaku mulia seperti yang dipesankan oleh Nabi Muhammad saw.

\section{Sastra Profetik Kuntowijoyo}

Profetik berasal dari kata prophetic yang berarti kenabian atau berkenaan dengan nabi. Kata dari bahasa Inggris ini berasal dari bahasa Yunani "prophetes" sebuah kata benda untuk menyebut orang yang berbicara awal atau orang yang memproklamasikan diri dan berarti juga orang yang berbicara masa depan. Profetik atau kenabian di sini merujuk pada dua misi yaitu seseorang yang 
menerima wahyu, diberi agama baru, dan diperintahkan untuk mendakwahkan pada umatnya disebut rasul (messenger), sedang seseorang yang menerima wahyu berdasarkan agama yang ada dan tidak diperintahkan untuk mendakwahkannya disebut nabi (Prophet) (Roqib, 2011: 49).

Sastra profetik di Indonesia pertama kali dipopulerkan oleh Kuntowijoyo pada tahun 80-an. Pada acara Temu Sastra tahun 1982 di Taman Ismail Marzuki, Kuntowijoyo (dalam Hadi W.M., 1999: 23) menyampaikan makalahnya "Saya Kira Kita Memerlukan juga Sebuah Sastra Transendental.” Dalam acara tersebut pula, Kuntowijoyo menyinggung perlunya kembali menegakkan etika profetik di dalam karya sastra. Sedangkan menurut Anwar, karya sastra profetik adalah karya sastra yang ketat dalam struktur (ada pergulatan bentuk ucap)" sekalipun memiliki kaitan dengan Yang Maha Abadi". Tidak heran jika karya sastra yang demikian (yang sebenar-benarnya karya sastra) selalu mampu melampaui zamannya (Anwar, 2007: 154).

Kebaruan ilmu profetik ini, menurut Kuntowijoyo (2006: 93-96) merupakan pengembangan jawaban atau kritik atas ilmuilmu sosial yang selama ini telah ada. Fungsionalisme gaya Amerika dalam sosiologi, marxisme, feminisme, liberalisme, maupun perfeksionis merupakan ilmu sosial yang mendapat tempat tersendiri di kalangan masyarakat Barat. Lebih lanjut, Kuntowijoyo mengatakan ilmu sosial yang telah ada selama ini hanya menekankan pada bagian tertentu saja, tidak terlalu memberi kemaslahatan pada sebagian besar umat (masyarakat). Adanya pembatas-pembatas tertentu dari berbagai macam ilmu sosial membuat kritikan yang kesemuanya mengarah pada sesuatu yang memperhatikan nilai (perfeksionis, berpihak). Oleh karena itu, diperlukan sebuah disiplin ilmu yang demokratis, mengandung nilai-nilai agama (Islam) dan berpihak pada umat (masyarakat).

Sastra profetik ini, menjadi sebuah sastra dialektik; sastra yang berhadapan dengan realitas, melakukan penilaian dan kritik sosial budaya secara beradab. Tidak hanya menyerap dan mengekspresikan sesuatu, akan tetapi sastra profetik juga memberi arah realitas (Kuntowijoyo, 2006: 1-2). Abdul Hadi (2004: 12) menyatakan bahwa Sastra profetik merupakan tindak lanjut dari semangat profetik yang memiliki tujuan mengembalikan keselarasan antara dimensi sosial dan dimensi transendental dalam kehidupan manusia. Dengan gagasan baru Kuntowijoyo melalui sastra profetik ini, menjadikan khasanah kebudayaan Islam semakin lengkap.

Dalam sastra profetik terdapat asas yang digunakan sebagai pedoman bagi seseorang untuk melakukan tindakan meniru perbuatan kenabian. Etika itu sendiri berarti kumpulan asas atau nilai yang berkenaan dengan akhlak. Etika juga dapat dipahami sebagai asas yang mendasari perilaku sehingga dapat menjadi pedoman. Etika dalam konteks sastra profetik adalah etika profetik. Etika itu disebut "profetik" karena ingin meniru perbuatan nabi (Kuntowijoyo, 2006: 16). Dengan demikian, etika profetik adalah asas yang menjadi pedoman bagi seseorang untuk melakukan tindakan meniru perbuatan kenabian. Oleh karena itu, etika sastra profetik adalah asas yang menjadi pondasi bagi sastrawan dalam menulis sastra yang mengemban misi kenabian. Oleh sebab itulah etika sastra profetik adalah asas yang digunakan sebagai pondasi bagi sastrawan menciptakan karya sastra yang mengandung muatan kenabian.

Etika sastra profetik bersumber pada Q.S. 3: 110, yang di dalamnya menjelaskan bahwa "Kamu adalah umat terbaik yang dilahirkan untuk manusia menyeruh kepada yang ma'ruf (kebaikan) dan mencegah dari yang munkar (kejahatan), serta beriman kepada Allah SWT". Ayat tersebut oleh Kuntowijoyo dijadikan tiang utama konstruksi sastra profetik. Ayat ini kemudian diejawantahkan dalam tiga konsep etika profetik, yaitu humanisasi (amar ma'ruf), liberasi (nabi munkar) dan transendensi yaitu beriman kepada Allah SWT (tu'minuna billah). 
Adapun yang menjadi puncak pencapaian estetika karya sastra (profetik) adalah tatkala sastra mampu mempertemukan kebenaran dan religiusitas dengan keindahan (Noor, 2011: 82). Artinya, sebuah karya sastra yang baik adalah karya yang mampu mengemas religiusitas secara indah kepada pembacanya. Pada mulanya, segala sastra adalah religius. Dialektika dalam sastra profetik menyatukan dua dimensi penting dari kehidupan manusia, yaitu dimensi sosial dan dimensi transendental. Inilah menjadi tujuan utama dari sastra religius. Religius berakar pada kata religi dan religio (Bahasa Latin) yang berarti perasaan keagamaan. Perasaan keagamaan ini merupakan segala bentuk perasaan batin yang berhubungan dengan Tuhan, seperti; takut, dosa dan kekaguman pada kebesaran Tuhan. Religiositas harus didasari dengan niat berbuat kebaikan kepada sesama. Dengan demikian, sastra religius adalah sastra yang mempersoalkan dimensi kemanusiaan dalam kaitanya dengan dimensi transendental.

\section{Tiga Pilar Sastra Profetik}

Pendidikan profetik adalah proses transfer pengetahuan (knowledge) dan nilai (values) yang bertujuan untuk mendekatkan diri kepada Tuhan dan alam sekaligus memahaminya untuk membangun komunitas sosial yang ideal (khairul ummah). Pendidikan profetik peserta didiknya dipersiapkan sebagai individu sekaligus komunitas untuk itu standar keberhasilan pendidikan diukur berdasarkan capaian yang menginternal dalam individu dan yang teraktualisasi secara sosial (Roqib, 2011: 88).

Lebih jauh lagi, pendidikan profetik ini memiliki tujuan meniru sifat-sifat nabi yang mempunyai ciri sebagai manusia yang ideal secara spiritual dan menjadi pelopor perubahan, membimbing masyarakat ke arah perbaikan dan melakukan perjuangan tanpa henti melawan penindasan. Misalnya tugastugas kenabian yang bermuatan sifat-sifat mulia yaitu: Jujur (al-sidq), Amanah (al- amanah), Komunikatif (al-tablig) dalam arti selalu menyampaikan ajaran dan kebenaran; dan Cerdas (al-fatanab). Atau bisa disimpulkan bahwa pendidikan profetik dapat dipahami sebagai seperangkat teori yang tidak hanya mendeskripsikan gejala sosial yang tidak hanya bertujuan untuk merubah, namun lebih dari itu diharapkan dapat mengarahkan perubahan atas dasar cita-cita etik dan profetik. Adapun tiga pilar profetik ini berupa:

\section{Transendensi}

Transendensi berasal dari bahasa Latin "transcendere" yang berarti naik ke atas; dalam bahasa inggris "to transcend" berarti menembus, melewati, melampui, atau perjalanan di atas atau di luar. "transcend" berarti melebihi, lebih penting dari, "transcendent" berarti sangat, teramat, sukar dipahamkan, diluar pengertian dan pengalaman biasa. Transendensi bisa diartikan sebagai Hablun min Allah, ikatan spiritual yang mengikatkan antara manusia dan Tuhan. Transendensi dalam teologi Islam berarti percaya kepada Allah, kitab Allah dan yang ghaib (Roqib, 2011: 78).

Dalam konteks agama, transendensi bisa diartikan sebagai hubungan vertikal atau spiritual manusia dengan Tuhan (Hablun min Allah). Ini menimbulkan hubungan spiritual yang bersifat individual (intuituf) dan sulit untuk dikomunikasikan secara verbal kepada orang lain dan yang mengerti hanyalah dirinya sendiri.

Berdasarkan pada filsafat profetik indikator transendensi dapat dirumuskan: a) Mengakui adanya kekuatan supranatural (Allah). b) Melakukan upaya mendekatkan diri kepada Allah. c) Berusaha untuk memperoleh kebaikan Tuhan sebagai tempat bergantung. d) Memahami suatu kejadian dengan pendekatan mistik (kegaiban), mengembalikan sesuatu kepada kemahakuasaanNya. e) Mengaitkan perilaku, tindakan dan kejadian dengan ajaran kitab suci. f) Melakukan sesuatu disertai harapan untuk kebahagiaan hari akhir (kiamat). g) 
Menerima masalah atau problem hidup dengan rasa tulus dan dengan harapan agar mendapat balasan di akhirat untuk itu kerja keras selalu dilakukan untuk meraih anugerahNya (Roqib, 2011: 79).

\section{Liberasi}

Liberasi dari bahasa Latin "liberare" berarti memerdekakan atau pembebasan. Liberation dari kata "liberal" yang berarti bebas. Liberation berarti membebaskan atau tindakan memerdekakan. Artinya pembebasan terhadap semua yang berkonotasi dengan signifikasi sosial seperti membela nasib buruh dan mengusir penjajah (Roqib, 2011: 82).

Adapun liberasi dalam konteks ilmu berarti bahwa semua ilmu didasari dengan nilai-nilai luhur transendental. Jika nilai-nilai liberasi dalam teologi pembebasan dipahami sebagai ilmu yang memiliki tanggung jawab profetik untuk membebaskan manusia dari kekejaman kemiskinan, dominasi struktur yang menindas dan hegemoni kesadaran palsu.

Dari definisi dan pemahaman terhadap filsafat profetik dapat dirumuskan indikator ilberasi yaitu: a) Memihak kepada kepentingan rakyat, wong cilik dan orangorang yang lemah (mustad"afin) seperti petani, buruh pabrik dan yang lainnya. b) Menegakkan keadilan dan kebenaran. c) Memberantas kebodohan dan keterbelakangan sosial-ekonomi. d) Menghilangkan kekerasan dan penindasan seperti pelacuran, KDRT, buman traficking dan lain sebagainya.

Selain itu dalam dunia pendidikan, pilar liberasi ini bisa dimaknai dengan penolakan terhadap komersialisasi pendidikan, kapitalisme pendidikan, dan lain sebagainya di mana banyak menimbulkan dampak negatif bagi pendidikan. pilar liberasi ini menjadi sebuah pembebas manusia dari segala sesuatu yang menjadikan manusia menjadi budak. Pesan liberasi ini bisa disampaikan melalui apa saja, tidak terkecuali karya sastra.

\section{Humanisasi}

Humanisasi berasal dari kata Yunani, bumanitas berarti makhluk. Dalam bahasa inggris buman berarti manusia, bersifat manusia, bumane berarti peramah, orang penyayang, bumanism berarti peri kemanusiaan. Humanisasi (insaniyyah) artinya memanusiakan manusia. Menurut Kuntowijoyo humanisasi diartikan sebagai menghilangkan kebendaan, ketergantungan, kekerasan, dan kebencian manusia.

Karena dalam pandangan Islam, manusia digambarkan sebagai makhluk yang merdeka karena hakekat kemerdekaan itulah menduduki tempat yang terhormat. Dalam Al-Quran banyak ayat yang menyerukan tentang pencarian esensi diri dari manusia, memikirkan kedudukannya dalam realitas sehingga mampu menempatkan dirinya sesuai dengan keberadaan kemanusiaannya.

Indikator Humanisasi: a) Menjaga persaudaraan meski berbeda agama, kayakinan, status sosial dan tradisi. b) Memandang seseorang secara total. c) Menghilangkan berbagai bentuk kekerasan. d) Membuang jauh sifat kebencian terhadap sesama (Roqib, 2011: 84). Humanisasi ini merupakan tugas besar dari pendidik yaitu memanusiakan manusia. Selain itu juga pentingnya menempatkan derajat manusia dalam artian melalui pendidikan ini, manusia dapat diangkat fitrahnya sebagai sebaikbaiknya makhluk dan bermartabat kemanusiaan.

Semua hal tersebut menjadi sebuah visi profetik di dalam sebuah pendidikan melalui karya sastra. Unsur-unsur profetik tersebut harus menjadi tema pendidikan Islam. Setiap pendidikan Islam harus menyertakan unsur transendensi. Dalam pandangan Islam, manusia digambarkan sebagai makhluk yang merdeka karena hakikat kemerdekaan itulah menduduki tempat yang terhormat. 


\section{Kepenyairan Abdul Wachid B.S. dalam Kesusatraan Indonesia}

Abdul Wachid B.S., dilahirkan di dusun terpencil Bluluk, Jawa Timur, 7 Oktober 1996. Dia adalah putera pertama dari Ibu Siti Herawati, binti Muhammad Usmuni, bin Muhammad Dahlan dan ayahnya Muhammad Abdul Basyir, bin Masyhuri Wiryosumarto, bin Kromodimejo, bin Kartodimejo, bin Muhammad Muso Suromangunjoyo (Wachid B.S., 2017: 117).

Semasa Ia duduk di bangku SD, bakat kepenulisan dan kepenyairan Abdul Wachid B.S. sebenarnya sudah mulai muncul. Di mulai dari buku Sastra Pelangi Indonesia, karya Sutan Takdir Alisjahbana. Dari buku itulah akhirnya Abdul Wachid B.S. mulai mempelajari puisi dimulai dari karya-karya Amir Hamzah. Pada saat pindah di Yogyakarta semasa melanjutkan SMAnya, Abdul Wachid B.S. bertemu dengan guru Bahasa Indonesia yang bernama Drs. Nursisto. Dari guru Bahasa Indonesianyalah ia belajar teater dengan tekun untuk pementasan di TVRI Yogyakarta. Setelah itu, dia diajari menulis puisi dan mulai dimuat di koran Kedaulatan Rakyat. Setelah itulah Abdul Wachid B.S. lebih produktif lagi dalam menulis. Sebagian sajak Abdul Wachid B.S. terdokumentasi dalam antologi: Sembilu (Dewan Kesenian Yogya, 1991), Serayu (Harta Prima Press, 1995), Lirik Lirik Kemenangan (Taman Budaya Yoga, 1994), Negeri Poci-3 (Tiara Jakarta, 1996), Mimbar Penyair Abad 21 (Balai Pustaka, 1996), Tamansari (Festival Kesenian Yogya X, 1998), Angkatan sastra 2000 (Grasindo, 2000), Hijau Kelon (Kompas, 2002), Medan Waktu (Cakrawala Sastra Indonesia, Dewan Kesenian Jakarta, 2004), Sauk Seloko: Bunga Rampai Puisi Pertemuan Penyair Nusantara VI (Dewan Kesenian Jambi, Desember 2012), Antologi 90 Penyair Yogyakarta Lintang Panjer Wengi di Langit Yogya (Pesan Trend Ilmu Giri, Maret 2014), Syair-syair Indonesia (Interlude dan Pujangga Press, Mei 2016) dan lain sebagainya.
Sementara itu, buku tunggal yang menghimpun karya Abdul Wachid B.S. antara lain: Rumah Cahaya (kumpulan puisi), Sastra Melawan Slogan (kumpulan esai 2000 dengan catatan penutup Dr. Faruk.), Religiositas Alam: dari Surealisme ke Spiritualisme D. Zawawi Imron (buku ajar yang diberi kata pengantar oleh Prof. Dr. Rachmat Djoko Pradopo), Ijinkan Aku Mencintaimu (kumpulan puisi tahun 1986-2002),Tunjamu Kekasih (kumpulan puisi 2003), Beribu Rindu Kekasibku (kumpulan puisi 2004 yang diberi kata pengantar oleh Dr. Ketrin Bendelpeneliti sastra Indonesia berkebangsaan Jerman), Membaca Makna dari Chairil Anwar ke A. Mustofa Bisri (Buku Kajian sastra, 2005), Sastra Pencerahan (kumpulan esai, 2005), Gandrung Cinta (kumpulan puisi yang diberi kata pengantar Dr. Sangidu, M.Hum.), Analisis Struktural Semiotik: Puisi Sirealistis Religius D. Zawawi Imron (kumpulan artikel yang diberi kata pengantar Prof. Dr. Rachmat Djoko Pradopo), Yang (kumpulan puisi 2011 yang diberi kata pengantar oleh Emertus Professor Virginia Hooker FAHA, Australia Nation University), Kepayang (kumpulan puisi, 2012), Hyang (kumpulan puisi, 2014), Nun (kumpulan puisi, 2017).

Tahun 2004 dan 2005, buku puisinya Rumah Cabaya dipilih oleh Departemen Pendidikan Nasional sebagai bacaab wajib bagi Sekolah Lanjutan Tingkat Atas, karenanya didokumentasi oleh perpustakaan SMA dan Madrasah Aliyah Negeri seluruh Indonesia. Sejak tahun 2003-sampai sekarang Abdul Wachid B.S juga diminta oleh Kementrian Pendidikan Nasional RI menjadi Juri Lomba Mengkritik Karya sastra (LMKS) dan Lomba Menulis Cerpen (Wachid B.S., 2017: 117-124).

Dia adalah alumnus dari Fakultas Ilmu Budaya, Jurusan Sastra Indonesia, Universitas Gadjah Mada pada tahun 1996. Di Pascasarjana UGM pula ia memperoleh gelar Magister Humaniora (M.Hum) dari program Study Sastra (2007). Sekarang Abdul Wachid B.S. sedang menulis disertasi untuk Program Study Doktor (S-3) Pendidikan Bahasa Indonesia (PBI) di 
Universitas Negeri Sebelas Maret (UNS) Surakarta (Wachid B.S., 2013: 98). Abdul wachid B.S. pernah menjadi dosen tamu untuk matakuliah Bahas Indonesia dan Ilmu Budaya Dasar di Sekolah Tinggi Ilmu Ekonomi Widya Wiwaha Yogyakarta (19982000); dosen tamu untuk matakuliahmatakuliah Ilmu Sastra di Universitas Muhammadiyah Purwokerto (1997-2013). Ia menjadi dosen tamu untuk matakuliah Apresiasi dan Kajian Puisi, Penulisan Karya Sastra, Puisi Lama dan Modern, Pengantar Teori Sastra di Universitas Ahmad Dahlan Yogyakarta (2008-sekarang). Di samping menulis karya sastra, Abdul Wachid B.S. menjadi dosen negeri di Institut Agama Islam Negeri (IAIN) Purwokerto (Wachid B.S., 2017: 125).

\section{Nilai Pendidikan Karakter dalam Buku Puisi Hyang Karya Abdul Wachid B.S.}

Membaca puisi-puisi yang terhimpun dalam buku Hyang karya Abdul Wachid B.S. ini, pembaca akan menemukan beraneka ragamnya nilai-nilai pendidikan karakter yang terkandung di dalamnya. Ciri khas dari puisi Abdul Wachid B.S. dalam buku Hyang ini sangat kental nilai religiusitasnya. Terutama bagaimana seorang penyair menceritakan dirinya (perilaku) atas nilainilai yang di dapat di dalam hidupnya. Ini menandakan bahwa dalam penulisan puisinya, penyair memiliki sudut pandang yang kuat dalam menulis puisi.

Selain dari aspek tersebut, terlihat makna yang terkandung juga sarat akan simbol akhlak karena memiliki keterkaitan dengan alam berpikir penyair. Ketika membaca buku Hyang, pembaca dituntut memiliki wawasan tentang alam pikir yang melatari penciptaan puisi. Ketika membaca buku Hyang pula, banyak nilai profetik yang disajikan oleh penyair dalam setiap sajaknya.

\section{Nilai Transendensi dalam Buku Puisi Hyang}

Dalam pola Islam, selalu ada upaya mencapai derajat tertinggi dalam kehidupan, yaitu dengan mengupayakan sikap yang terkait dengan nilai tauhid dan keimanan. Untuk mendapatkan kedua nilai tersebut yaitu dengan cara penyadaran, misalnya melalui Asmaul Husna. Begitu pula dalam puisi Wachid B.S. (2014: 70) yang memulai pencarian nilai-nilai ketauhidan sebagai landasan untuk bertindak dan berprilaku dalam hidup. Misalnya dalam sajak "Sembah Hyang", di dalam dua bait terakhir sangat jelas mengandung kesadaran penyair akan Pencipta alam semesta:

"duh gusti allah/ menyembah panjenengan/ bukan sebab keterbatasan/ justru cinta tahu semesta tak terhingga// maka/ hamba angkat tangan/ ke arah kiblat panjenengan/ allahu akbar...//"

Dari kedua bait di atas, sangat jelas bahwa aku-lirik di dalam puisinya memiliki kesadaran penuh akan keberadaan Tuhannya. Kesadaran tersebut direalisasikan dengan melaksanakan kewajiban aku-lirik sebagai seorang hamba dengan melaksanakan shalat. Hal ini terjadi setelah aku-lirik menyadari bahwa alam semesta ini begitu luas (dalam bait "justru cinta tahu semesta tak terhingga"). Ketawakalan ini termasuk ke dalam pekerjaan hati, di mana semua proses berlangsungnya hidup harus bergantung kepada Tuhan.

Sesuatu persolan tidak akan sanggup dihadapi oleh manusia tanpa bersandar kepada kekuatan Tuhan. Seperti halnya kepasrahan aku-lirik di dalam puisinya. Melalui sembahyang (shalat), aku-lirik menunjukkan ketundukkannya sebagai manusia. Dalam hal ini terdapat transendensi yang utuh dalam menyikapi ketauhidan. Seperti halnya dalam berdoa di dalam shalat, ekspresi hubungan aku-lirik dengan Tuhannya terjadi secara langsung. Seperti halnya dalam surat Al-Mu'min ayat 60: 


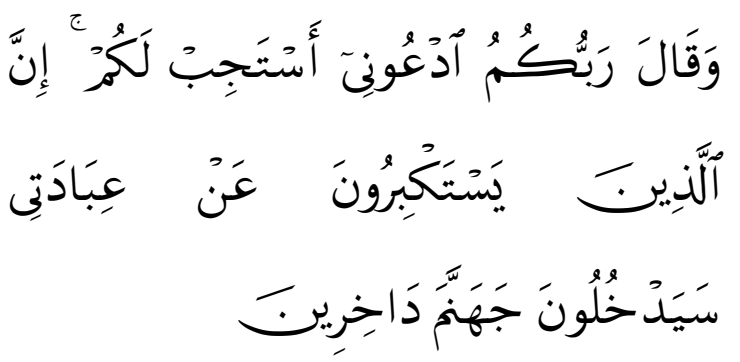

Artinya: "Dan Tubanmu berfirman: "Berdoalah kepada-Ku, niscaya akan Kuperkenankan bagimu. Sesunggubnya orang-orang yang menyombongkan diri dari menyembah-Ku akan masuk neraka Jahannam dalam keadaan bina dina"

Melalui perantara doa di dalam shalat tersebut, terkandung doa, nilai kepasrahan, dan segala bentuk kesadaran diri aku lirik setelah mengamati realitas alam semesta berserta isinya. Hal lain juga muncul dalam puisi berjudul "Ya Allah Hyang" (Wachid B.S., 2014: 42). Di bait pertamanya kita langsung menumakan nilai transenden yaitu: maha awal yang/ maha akhir yang/ maha dlahir yang/ maha batin// yang berbelaskasihanilah hambamu yang/ rapuh seperti daun tanggal dari.

Ungkapan ketundukan aku-lirik ditunjukkan melalui Asmaul Husna. Dalam sajak tersebut, aku-lirik mempercayai penuh nama-nama Allah yang berjumlah 99 tersebut sehingga memunculkan keimanan di dalam diri aku-lirik. Melalui asmaul husna pula yang menjadi salah satu jalan untuk mengenali Dzat Allah, karena wujud Allah tidak bisa dicapai oleh akal pikiran. Seperti dalam hipogram pembuatan puisi tersebut yaitu surat Al-Hadid ayat 3:

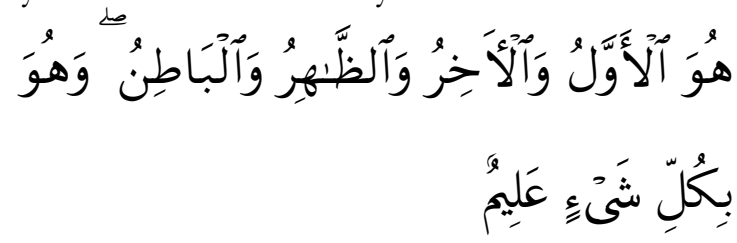

Artinya: "Dialah yang Maha Awal dan yang Akbir yang Zhabir dan yang Bathin; dan dia Maha mengetabui segala sesuayu"

Melalui asmaul husna tersebut, menjadikan aku-lirik merasa tidak berdaya (belaskasihanilah hambamu yang rapuh) karena dalam puisi tersebut, aku lirik sadar benar mengenai Kemahakuasaan Allah dari ciptaan yang telah ada seperti alam semesta ini. Ketauhidan tersebut adalah upaya akulirik untuk mengenal Allah melalui sifat-Nya, takut kepada-Nya, dan melaksanakan perintah-Nya.

Keyakinan tersebut menandakan bahwa dalam puisi di atas, adalah gambaran kehidupan spiritual dan perilaku penyair dalam memandang suatu realitas (baik batin maupun lahir). Keyakinan tersebut menjadi sebuah modal untuk menunjukkan ke-Esaan Allah dalam menjalani kehidupan. Dimensi ketuhanan inilah yang dijadikan landasan hidup baik untuk berprilaku kepada diri sendiri ataupun berprilaku kepada orang lain.

Dari uraian di atas, kita bisa menyimpulkan bahwa berawal dari sebuah puisi yang memiliki nilai kesadaran diri terhadap memandang realitas ketuhanan, muncul dimensi-dimensi spiritual yang disajikan oleh penyair. Dalam kaitannya dengan pendidikan profetik, puisi ini menyuguhkan nilai transendensi yang berupa tawakal (berdoa dan shalat), ketauhidan, iman, takwa, dan berzikir. Dari sini terjadi transfer pengetahuan dan nilai untuk mengEsakan Allah yang dilakukan oleh penyair melalui puisinya disertai dengan pemahaman atas bentuk ketauhidan bahwa dalam diri manusia ada kelebihan dan kelemahan yang menunjukkan adanya campur tangan Tuhan (yang transenden).

\section{Nilai Liberasi dalam Buku Puisi Hyang}

Sastra adalah bagian dari pembebasan jiwa manusia. Banyak pula para penyair yang menjadikan sastra sebagai media untuk menyerukan aspirasi berkaitan dengan kehidupan sosial. Misalnya di dalam buku puisi Hyang, Abdul Wachid B.S. (2014: 35) sangat jelas menggambarkan hal tersebut melalui beberapa puisinya. Misalnya saja dalam puisi yang berjudul "Setiap Kepak Sayap Kupukupu". Dalam bait keduanya penyair mengungkapkan nilai liberasi melalui kalimat: "menjadikan aku memberi/ apa saja yang kupandang baik/ untuk orang lalulalang 
yang/ kujumpai, berpapasan di taman ini/ bertabik"

Dalam bait tersebut aku-lirik mengungkapkan bahwa ia sendiri memberikan suatu kebaikan kepada orangorang yang dijumpainya. Kebaikan tersebut bisa diartikan sebagai zakat ataupun sodakoh yang diberikan kepada orang yang tidak mampu. Karena pada dasarnya setiap manusia haruslah saling tolon-menolong satu sama lainnya. Di dalam puisi lain juga terlihat ungkapan penyair dalam puisi yang berjudul "Berterimakasihlah" (Wachid B.S., 2014: 36).

\section{"berterimakasihlah}

kepada

tangantangan yang/ masih memberi/ setiap kebaikan/ kauaku berterima karena/ setiap kebaikan yang/ panjang yang meluas yang/ sebagai tangannya merengkuh/ langit dan bumi dengan/ cinta dan kasihsayang yang/ tidak berkesudahan."

Dalam bait ini, kesadaran aku-lirik atas tindakannya terhadap sesama manusia haruslah saling menolong (berterimakasihlah kepada tangantangan yang/ masih memberi). Pertolonngan tersebut pastilah karena sebuah cinta atau rasa kasih sayang yang muncul di dalam diri aku-lirik. Perilaku ini muncul setelah aku-lirik melihat sebuah realitas dalam kehidupannya. Ini bisa berupa banyaknya tetangga, orang miskin yang ada di sekitarnya, ataupun banyaknya pengemis yang dilihat oleh aku-lirik.

Realitas tersebut oleh penulis dipandang sebagai bentuk kesadaran akulirik yang beragama Islam. Ketauhidan ini akan menjadi abadi karenanya menuntut perubahan yang permanen yaitu dengan membantu sesama (bablun min an-nas) yang disertai dengan cita-cita mengenai tujuan (a sense of goal) yaitu membuat manusia lebih dekat dengan Tuhan.

Dari sini, penulis menyimpulkan bahwa puisi di atas mengandung nilai pendidikan karakter berupa liberasi yang ditunjukkan melalui perilaku baik antar sesama manusia (orang yang membutuhkan). Telihat dari cara Abdul Wachid B.S. mengungkapkan realitas dalam kehidupannya dan diungkapkan dalam puiai yang mengandung nilai kesadaran terhadap sesama, membantu orang yang yang lemah, rasa cinta dan kasih sayang (anti kekerasan), dan kesadaran diri sebagai makhluk sosial dengan keyakinan akan Tuhan. Nilai liberasi ini, oleh penulis diproyeksikan sebagai upaya pembebasan atau memerdekakan. Baik berupa untuk pembebasan hak-hak yang semestinya dimiliki ataupun kebebasan menyuarakan kreatifitas dan tindakan postif atas kebebasan yang dimiliki.

\section{Nilai Humanisasi dalam Buku Puisi Hyang}

Manusia pada dasarnya adalah makhluk yang merdeka. Namun hal itu menjadi semakin pudar karena banyak manusia yang tidak menjalankan tugas sebagaimana mestinya. Misalnya manusia yang melakukan kekerasan, penindasan dan lain sebagainya. Ini menandakan bahwa manusia tidak menempatkan posisi sesama manusia tidak pada tempat yang semestinya. Seperti di dalam buku puisi Hyang, Abdul Wachid B.S. (2014: 58) menceritakan sebuah nilai humanisme melalui puisinya. Misalnya dalam puisi yang berjudul "Ahed Tamimi". ketika saudaramu diberondong/ moncong bazoka seorang tentara israel bermata batu/ ketika jalur gaza lakilaki lalulalang/ yahudi melulu dengan sepatu dan peluru/ ketika tanktank panser memburu/ perempuan dan anakanak lugu"

Dalam bait tersebut digambarkan dengan begitu jelas oleh aku-lirik tentang konflik yang terjadi di Palestina. Dominasi Israel untuk merebut daerah Yerusalem yang pada dasarnya merupakan sebuah wilayah bagian dari Palestina, menyebabkan banyak konflik di jalur Gaza. Realitas inilah yang ditangkap oleh aku-lirik yang merasa bahwa nilai kemanusiaan semakin pudar. Dengan melakukan kekerasan dan melakukan peperangan demi sebuah wilayah, banyak menimbulkan kematian dan kerusakan. Anak-anak kehilangan orang tuanya, tidak bisa bersekolah, kehilangan rumah dan 
sebagainya. Konflik kemanusiaan inilah yang oleh aku-lirik disuarakan melalui puisi.

Banyaknya Tank Panser, peluru, bazoka dan senjata lainnya, kedudukan manusia yang lemah kalah dengan kedudukan manusia yang memiliki kekuasaan dan kekuatan. Sehingga dalam batin aku-lirik juga tersampaikan sebuah kesedihan dan keprihatinan, misalnya dalam bait: "mana yang lebih manusia/ mana yang lebih binatang melata". Melalui ungkapan tersebut, aku-lirik mencoba membandingkan dengan binatang yang melata (binatang yang tak mempunyai mata). Padahal manusia itu sendiri mempunyai mata yang digunakan untuk melihat. Tapi mengapa berbuat keji terhadap sesama manusia? Inilah yang disuarakan oleh aku lirik tatkala terjadi sebuah kedzaliman yang dilakukan oleh manusia.

Humanisasi ini berawal dari transendensi dan humanisasi, keduanya disublimasikan secara detail sehingga pesan profetik di dalam puisi tersebut tersampaikan secara halus. Dalam konteks pendidikan profetik, puisi tersebut juga mengandung nilai persaudaraan, menjaga kedamaian antar-sesama manusia, status sosialekonomi, memandang untuh manusia secara total, dan menghormati sesama.

Humanisasi ini sangat kita perlukan, sebab ada tanda-tanda bahwa masyarakat kita sedang menuju ke arah dehumanisasi. Dehumanisasi ialah objektivasi manusia (teknologis, ekonomis, budaya, massa, negara), agresivitas (kolektif, perorangan, kriminalitas), loneliness (privatisasi, individualisasi), dan spiritual alienation (keterasinga spiritual. Dalam dehumanisasi perilaku manusia lebih dikuasai bawah sadarnya daripada kesadarannya. Dehumanisasi telah menggerogoti masyarakat Indonesia yang tampak dalam beberapa hal, yakni (1) terbentuknya manusia mesin, (2) manusia dan masyarakat massa, dan (3) budaya massa (Kuntowijoyo, 2006: 23).

Penerapan pendidikan karakter melalui puisi profetik dalam pendidikan agama Islam menjadikan nilai keunggulan tersendiri pada proses pendidikan Islam. Dengan adanya pemahaman yang benar terhadap Islam maka akan menghasilkan paradigma Islam yang integralistik atau menyeluruh. Pendidikan agama Islam yang berparadigma profetik dalam penerapannya membutuhkan metodologi baru yaitu metodologi integralisasi dan objektifikasi (Kuntowijoyo, 2007: 49). Pemikiran pendidikan dalam paradigma profetik dengan ketiga pilar yang telah disebutkan sebelumnya, diharapkan bisa diartikulasikan dan aktualisasikan dalam praktik pengembangan Pendidikan Islam.

\section{KESIMPULAN}

Tidak hanya mengandung estetika bahasa saja, puisi Abdul wachid B.S. juga mengandung muatan karakter yang bila dilihat dari puisi poretik sejalan dengan sastra profetik Kuntowijoyo. Muatan nilai pendidikan karakter ini, sangat banyak seperti yang terkandung dalam puisi Hyang karya Abdul Wachid B.S. Bila dilihat dari sastra profetik Kuntowijoyo, terbagi ke dalam tiga pilar urama: transendensi (tu'minuna billah), humanisasi (amar makruf) dan liberasi (nabi munkar).

Nilai pendidikan profetik berupa nilai transenden terlihat dari puisi-puisi yang mengandung nilai ketauhidan, keimanan, dan kesadaran sebagai hamba Allah yang digunakan oleh penyair sebagai landasan hidup. Nilai liberasi juga disampaikan melalui pusisi yang mengandung nilai kepedulian sosial sebagai hubungan antar-sesama manusia. Sedangkan nilai humanisasi terlihat dari puisi-puisi Abdul Wachid B.S. yang banyak membicarakan mengenai persaudaraan, menjaga kedamaian antarsesama manusia, status sosial-ekonomi, memandang untuh manusia secara total, dan menghormati sesama.

Penerapan pendidikan karakter melalui puisi profetik ini, menjadi sebuah keunggulan dalam transfer nilai pendidikan Islam. Konstruk pemikiran dan perilaku 
penyair yang disajikan melalui puisi ini memberikan pemahaman akan nilai-nilai karakter yang dimiliki oleh penyair. Selain itu, sastra profetik juga bisa dijadikan sebagai pembelajaran pendidikan karakter yang bersifat integratif. Dari sinilah akan muncul metode dalam pembelajaran baru melalui karya sastra. Dimulai dari pemahaman terhadap sastra profetik yang bersumber dari cerminan sifat-sifat mulia nabi: Jujur (al-sidq), Amanah (al-amanah), Komunikatif (al-tablig) dalam arti selalu menyampaikan ajaran dan kebenaran; dan Cerdas (al-fatanah).

\section{DAFTAR PUSTAKA}

Anwar, Wan. (2007). Kuntowijoyo; Karya dan Dunianya. Jakarta: Grasindo.

Arifin, Zaenal. (2002). Moralitas Al-Qur'an dan Tantangan Modernitas. Semarang: Gama Media.

Hadi W.M., Abdul. (1999). Kembali Ke Akar Kembali Ke Sumber. Jakarta: Pustaka Firdaus. . (2004). Hermeneutika, Estetika, dan Religiusitas, Yogyakarta: Matahari.

Hamid, Hamdani dan Saebani, Beni Ahmad. (2013). Pendidikan Karakter Perspektif Islam. Bandung: Pustaka Setia.
Koesoema, Doni. (2007). Pendidikan Karakter: Strategi Mendidik Anak di Zaman Global. Jakarta: Grasindo.

Kuntowijoyo. (2006). Maklumat Sastra Profetik. Yogyakarta: Grafindo Litera Media. (2007). Islam Sebagai Ilmu: Epistemologi, Metodologi dan Etika. Yogyakarta: Tiara Wacana.

Mawardi, Kholid. (2013). "Seni Sebagai Ekspresi Profetik". Ibda. Volume 11, No. 2, Juli-Desember. pp. 131-147.

Noor, Acep Zamzam. (2011). Puisi dan Bulu Kuduk. Bandung: Nuansa Cendekia.

Pusat Bahasa Departemen Pendidikan Nasional. (2008). Kamus Umum Bahasa Indonesia, Edisi Ketiga, Jakarta: Pusat Bahasa.

Roqib, Moh. (2011). Prophetic Education: Kontektualisasi Filsafat dan Budaya Profetik dalam Pendidikan. Purwokerto: STAIN Press.

Wachid B.S., Abdul Wachid. (2013). Kepayang. Yogyakarta: Cinta Buku. (2014). Hyang, Yogyakarta: Cinta Buku. (2017). Nun. Yogyakarta: Cinta Buku. 